\title{
From Laboratory Studies to the Field Applications of Advanced Oxidation Processes: A Case Study of Technology Transfer from Switzerland to Burkina Faso on the Field of Photochemical Detoxification of Biorecalcitrant Chemical Pollutants in Water
}

\author{
S. Kenfack, ${ }^{1}$ V. Sarria, ${ }^{2}$ J. Wéthé, ${ }^{3}$ G. Cissé, ${ }^{4}$ A. H. Maïga, ${ }^{3}$ A. Klutse, ${ }^{1}$ and C. Pulgarin ${ }^{5}$ \\ ${ }^{1}$ Département de Recherche et Projets de Démonstration (REPRODEM), Centre Régional pour l'Eau potable et \\ l'Assainissement (CREPA), 03BP 7112 Ouagadougou 03, Burkina Faso \\ ${ }^{2}$ Departamento de Quimica, Universidad de los Andes, Cra 1 No 18A-10, Bogota, Colombia \\ ${ }^{3}$ Unité Thématique d'Enseignement et de Recherche en Gestion et Valorisation de l'Eau et de l'Assainissement (UTER-GVEA), \\ Institut International d'Ingénierie de l'Eau et de l'Environnement, 01 BP 594 Ouagadougou 01, Burkina Faso \\ ${ }^{4}$ Centre Suisse de Recherche Scientifique de Côte d'Ivoire (CSRS), 01 BP 1301 Abidjan 01, Cote d'Ivoire \\ ${ }^{5}$ Ecole Polytechnique Fédérale de Lausanne, Institute of Chemical Sciences and Engineering, GGEC, Station 6, CH, \\ 1015 Lausanne, Switzerland
}

Correspondence should be addressed to S. Kenfack, skenfack@yahoo.fr

Received 26 February 2009; Accepted 4 May 2009

Recommended by Mohamed Sabry Abdel-Mottaleb

The Fenton and photo-Fenton detoxification of non-biodegradable chemical pollution in water was investigated under simulated UV light in the laboratory and under direct sunlight in Ouagadougou, Burkina Faso. The laboratory experiments enable one to make a systematic diagnosis among three types of wastewaters, identifying a biorecalcitrant wastewater containing the Chlorohydroxy-Pryridine (CHYPR). The application of the photo-Fenton process on effluent containing the CHYPR showed not to stimulate the generation of biodegradable by-products. Optimal conditions for detoxification of effluent containing the CHYPR were found at $\mathrm{pH}=2.8,\left[\mathrm{Fe}^{2+}\right]=5.2 \mathrm{mM}$, initial $\left[\mathrm{H}_{2} \mathrm{O}_{2}\right]=768 \mathrm{mM}$, for an effluent concentrated at $2.2 \mathrm{mM}$ of CHYPR. The application of the photochemical process on a field pilot solar photoreactor for the detoxification of water polluted with a pesticide made with Endosulfan showed very promising results, with potential biodegradable effluents obtained at the end of the photochemical treatment. Optimal conditions of the applied study were found at $\mathrm{pH}=3 .\left[\mathrm{H}_{2} \mathrm{O}_{2}\right]=8 \mathrm{mM}$ and $\left[\mathrm{Fe}^{2+}\right]=0.18 \mathrm{mM}$ for an initial concentration of $0.36 \mathrm{mM}$ of Endosulfan.

Copyright ( 12009 S. Kenfack et al. This is an open access article distributed under the Creative Commons Attribution License, which permits unrestricted use, distribution, and reproduction in any medium, provided the original work is properly cited.

\section{Introduction}

An estimation of the global world water pollution reveals that $60 \%-70 \%$ of the total pollution is due to the agricultural activities, $25 \%$ to $30 \%$ by industries, and the remaining $5 \%$ to $10 \%$ due to the domestic uses [1]. The report showed that, in the most optimistic cases, the water pollution from agricultural origin is mostly consisted of the residues of pesticide and contributes to at least $50 \%$ on the deterioration of the quality of natural waters (surface and subsoil waters). This is closely followed by the pollution of chemical industrial origin. In fact, more than 1000 new substances are marketed each year in the world whereas up to now the toxicological information on only 1000 to 2000 of these products is accessible [2].

Most of these substances are xenobiotic (c.a. foreign to life), and very often they are synthetic products. Indeed, xenobiotic substances are in general not easily biodegradable, and they cross the biological water treatment systems without being completely degraded or even sometimes not degraded at all.

Some of these substances such as the pesticides are recognized as cause of carcinogenic, mutagen effects, or of hormonal disruptions to the fauna, wild life, and human beings. 
To face these problems, waste treatment techniques such as incineration, wet oxidation, and activated carbon adsorption are often used. Unfortunately, these techniques are very expensive, and the environmental virtues of some of them are discussed.

However, biological processes remain the most economical and environmentally compatible alternative for wastewater treatment. Thus, it would be important to confirm the biorecalcitrancy of a wastewater before the application of a photocatalytic treatment. Moreover, biorecalcitrant wastewater could only be photocatalytically treated up to the point where its biodegradability is enough to let the phototreated water follows a biological treatment. Two case studies are reported in this paper to illustrate the strategy of enhancing the biodegradability of biorecalcitrant wastewaters throughout a photocatalytic process. These studies are representative of two problem solving approaches: one in an industrial developed country (Switzerland) and the other in a tropical developing country (Burkina Faso).

\subsection{The Laboratory Solving Problem Approach in Switzerland versus the Field Applied Approach in Burkina Faso}

\subsubsection{Case Study 1: The Chemical Pollution in Wastewater in a} Swiss Manufacture. In June 2004, a Swiss chemical company started the manufacture of a new significant chemical, following a three-step process. Three types of effluent of a specific composition were generated at each step, and all the three effluents were mixed to other effluents of the manufacture and treated in an activated sludge wastewater treatment plant. Before the new production, the yield of the wastewater treatment plant was efficient, and it could respect the legal rejection norms. But since the production of the new chemical has started, the yield has fallen down and the plant could not any more respect the standards, even when the hydraulic capacity overshooting of the treatment plant was still very low. The laboratory study aimed at making a diagnosis identifying the biorecalcitrant effluent and studied its degradation using the photoFenton treatment process.

1.1.2. Case Study 2 The Problem of Persistent Organic Pollutants and Obsolete Pesticides in Burkina Faso. In order to implement the national plan of the Stockholm's Convention on the persistent organic pollutants (POPs), the government of Burkina Faso carried out in 2001 and 2004 two inventories of stocks of POPs pesticides available on the extent territory of Burkina Faso. Table 1 reports the results of these inventories.

It was noticed that $90 \%$ of these pesticides were formulated with Cypermethrin (67\%) and Endosulfan (3\%) which are classified in the categories II and III (from the toxic to very toxic) by the WHO. The same report revealed that 13 contaminated sites of major importance are available in Burkina Faso. Since there is neither incinerator in Burkina Faso nor a specialized hazardous waste treatment plant, the experimental approach developed at the EPFL, Switzerland, was tested for the degradation of a pesticide containing Endosulfan, one of the chemicals which is known to generate toxic metabolites after a first step biological degradation [4].

\section{Experimental}

2.1. Materials and Apparatus. At the LBE-EPFL, the photocatalytic studies were performed using a $50 \mathrm{~mL}$ Pyrex flask with a cut-off at $\lambda=290 \mathrm{~nm}$ placed into a Hanau Suntest (Figure 1).

The radiation source was a Xenon lamp where the radiant flux $\left(80 \mathrm{~mW} \cdot \mathrm{cm}^{-2}\right)$ was measured with a power meter of YSI Corporation. The lamp had a regular distribution of wavelengths with about $0.5 \%$ of the emitted photons at wavelengths shorter than $300 \mathrm{~nm}$ (UV-C range) and about $7 \%$ between 300 and $400 \mathrm{~nm}$ (UV-B range). The profile of the photons emitted between 400 and $800 \mathrm{~nm}$ (UV-A range) followed the solar spectrum.

Experiments were done at the light intensity of $560 \mathrm{~W}$. $\mathrm{m}^{-2}$, which corresponds to a relative UVA $(300-400 \mathrm{~nm})$ intensity of $\mathrm{W} \cdot \mathrm{m}^{-2}$. All the chemicals $\left(\mathrm{FeSO}_{4}, 7 \mathrm{H}_{2} \mathrm{O}\right), \mathrm{HCl}$ and $\mathrm{H}_{2} \mathrm{O}_{2}(30 \% \mathrm{w} / \mathrm{w})$ were bought from Fluka (Switzerland), and all were analytical grade (p.a.).

Three types of wastewaters (see Table 1) containing pyridine compounds were received from DLK Technology S.A, a Swiss company specialized in the developing specific technical plants for water and wastewater treatment.

The pilot plant, a SOLARDETOX ACADUS-2003 device model delivered by Ecosystem SA, Barcelona, Spain, is a one plate Compound Parabolic Concentrator (CPC) module (collector useful surface: $2.12 \mathrm{~m}^{2}$, photoreactor active volume $15.1 \mathrm{~L}$ within a total volume of $16.07 \mathrm{~L}$ ) made of sixteen borosilicate cylindrical glass tubes. Each tube lies on a CPC aluminum mirror with one sun of concentration.

The reactor is mounted on a two-position fixed platform inclinable at $10^{\circ}$ and $35^{\circ}$ allowing operating at the approximate local latitude of Ouagadougou-Burkina Faso $\left(12.2^{\circ} \mathrm{N}\right)$, at $10^{\circ}$ angle position most of the time. A picture and the technical design of the CPC photoreactor used are shown in Figure 2.

From the operational point of view, the plant behaves a plug-flow reactor in the collector zone, connected to a $50 \mathrm{~L}$ polypropylene stirred tank (recirculating tank or buffer tank) for wastewater preparation: $\mathrm{pH}$ adjustments, catalyst, and oxidant feeding. The ensemble constituted by a plug-flow reactor in the collector zone plus a tank and a recirculation system is equivalent to a batch photoreactor.

2.2. Procedures. In the laboratory, a systematic diagnosis including the characterization of each of the three effluents received was first made, followed by the photoassisted studies on the effluent containing chloro-2-pyridin. 2 liters of the raw effluent were first acidified at $\mathrm{pH}=3$. For the photodegradation processing, $50 \mathrm{~mL}$ of this preparation was put into a $60 \mathrm{~mL}$ of a Pyrex flask glass, and reactants (iron and peroxide) were added. The flask glass was placed into the Suntest photoreactor for a determined time of illumination. Samplings were made every 10 minutes for TOC, HPLC, and spectrophotometric analyses, and during the Zahn Wellens tests sampling were made daily.

The field application took place at the International Institute of Water and Environmental Engineering (2iE), Ouagadougou, Burkina Faso $\left(12^{\circ} 21^{\prime} \mathrm{N}, 1^{\circ} 31^{\prime} \mathrm{W}\right)$. It is an 


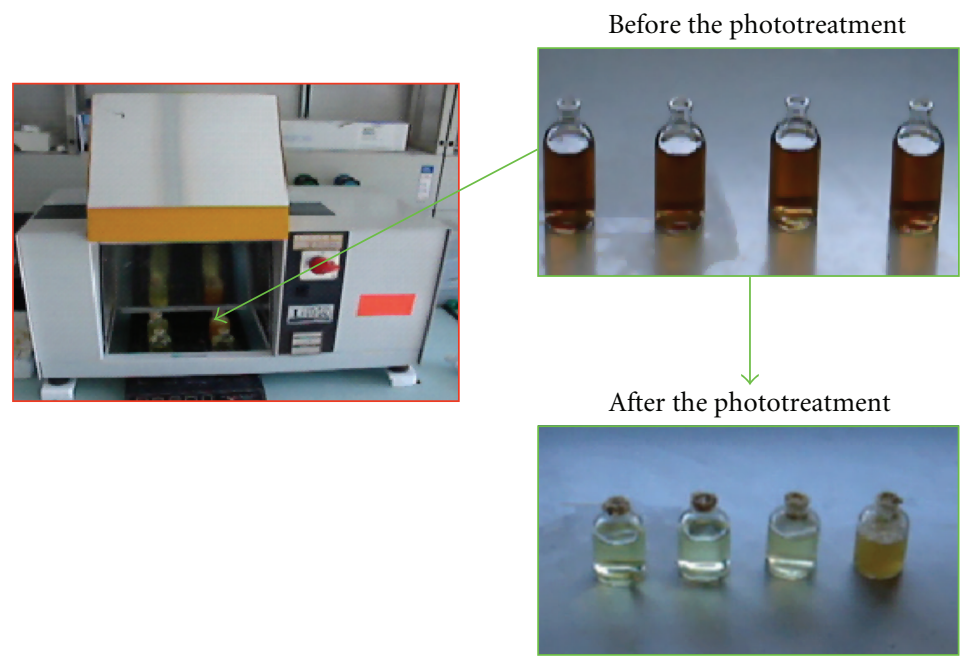

Figure 1: A Hanau Suntest Simulator containing 04 Pyrex flask samples during a laboratory processing at the BE-EPFL, Lausanne, Switzerland.

TABLE 1: Results of the surveys of POPs and obsolete pesticides in Burkina Faso (2001 and 2004) [3].

\begin{tabular}{|c|c|c|c|c|}
\hline \multirow{2}{*}{ Form } & \multicolumn{4}{|c|}{ Quantity } \\
\hline & 2001 & 2004 & \multicolumn{2}{|c|}{ Nature of the pesticide in 2004} \\
\hline Contaminated empty containers $(-)$ & 1450000 & $120 ’ 000$ & \multirow{2}{*}{ Cypermethrin } & \multirow{2}{*}{ Endosulfan } \\
\hline Powder $(\mathrm{kg})$ & 26000 & 3000 & & \\
\hline Liquid (Liters) & 250000 & 130000 & 85700 & 4000 \\
\hline
\end{tabular}

ideal place where solar applied researches can be carried out with more than 300 days-2500 sunny hours per year (e.g., in Alméria, Spain, it is estimated up to 3000 sunny hours per year) [3].

At the beginning of an experiment, the mixture is homogenized to achieve a fixed concentration in the system, by circulating the preparation in a closed loop circuit (Tankpump-photoreactor-tank). A desired stock of pesticide solution was first dissolved in 2 liters of tap water and stirred for at least 2 hours in the laboratory. Afterward, the solution was poured into the conditioning tank of the photoreactor in which 20 liters of tap water were previously added. Three more liters of tap water were used to rinse the predissolved Pyrex flask and added to the conditioning tank. The $\mathrm{pH}$ of the solution was adjusted to 3 with $\mathrm{HCl}$, and the catalyst $\left(\mathrm{FeCl}_{3}\right)$ was added. The entire system was homogenized by closing the valves (1) and (3) and circulating the polluted water in a closed loop circuit for 15 minutes (see Figure 2).

Once the solution is ready, the required amount of hydrogen peroxide was added, and the feeding valve (1) was opened according to the water circulation speed needed for the operation. The water flow was varied by regulating the valve (1) to: $0.3,0.4$, and $0.5 \mathrm{~m} \cdot \mathrm{s}^{-1}$.

The solar ultraviolet radiation was determined during the experiments through a UVA radiometer ACADUS 85 UV mounted on the reactor, at the same angle $\left(10^{\circ}\right)$ as its plate part. It provides data in terms of incident UVA radiation per area unit $\left(\mathrm{W} \cdot \mathrm{m}^{-2}\right)$ and the accumulated energy $E_{(t)}$ on the $2.12 \mathrm{~m}^{2}$ surface of the photoreactor (in Wh). $E_{(t)}$ is linked to the instantaneous irradiance flux $(\overline{U V})$, the reactor total active area $(A)$, the water volume $(V)$, and the experiment duration $(t)$ by the following relation:

$$
E_{(t)}=E_{\left(t_{0}\right)}+\Delta t \times \overline{U V \times \frac{A}{V}} .
$$

2.3. Analytical Methods. At the LBE, HPLC analyses were carried out in a Varian 9065 unit provided with a Varian 9012 solvent delivery system, an automatic injector 9100 and a Varian Pro Star Variable (200-400 nm) diode array detector: 9065 Polychromic. All modules were piloted with a computer on which the Varian Star 5.3 software is installed for liquid chromatography data delivery. A reverse phase spherisorb silica column ODS-2 and a (70/30) (v/v) mixture of acetonitrile/water mobile phase were used to run the chromatography in isocratic mode at a flow rate of $1 \mathrm{~mL}$. $\min ^{-1}$. This technique allows the measuring of the main pollutant concentration in the solution and to follow the overall formation and decay of the aromatic and aliphatic byproducts during the process.

A Hitachi UV-vis U-3010 and a Biomate 3 model spectrophotometers were used, respectively, at the LBE and at the $2 \mathrm{iE}$, with a $1.0 \mathrm{~cm}$ quartz cell. The Hitachi UV-vis U-3010 spectrophotometer allowed generating the 


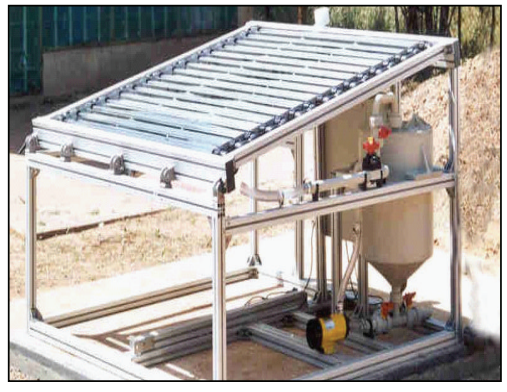

(a)

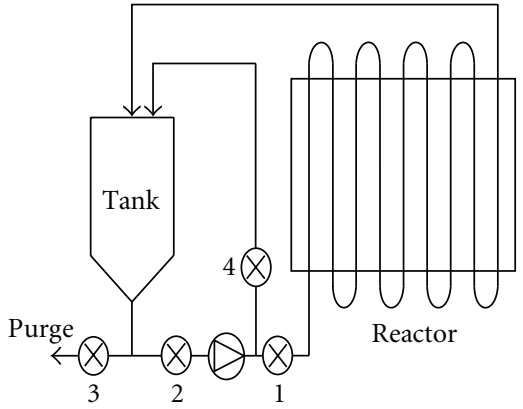

$\otimes$ Valve

$\otimes$ Pump

(b)

FIgure 2: A Picture and the technical design of the CPC photoreactor.

TABLE 2: Synthesis of the characteristics of the three effluents.

\begin{tabular}{|c|c|c|c|c|}
\hline Type of effluent & Main pollutant & Molecular structure & $\mathrm{pH}$ & $\operatorname{TOC}\left(g \cdot \mathrm{L}^{-1}\right)$ \\
\hline $\mathrm{WW}_{1}$ & CTFEP & 2-Chloro-3-(2,2,2-trifluorethoxy)-pyridin & 8.3 & 45 \\
\hline $\mathrm{WW}_{2}$ & LQV & Confidential & 6 & 43.5 \\
\hline $\mathrm{WW}_{3}$ & CHPYR & 2-Chloro-3-hydroxypyridin & 5.8 & 6.5 \\
\hline
\end{tabular}

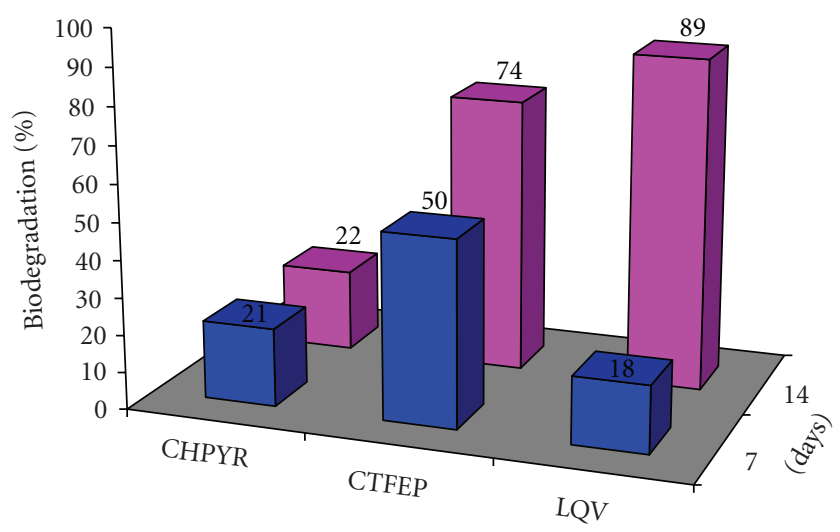

FIgURe 3: Percentage of biodegradation respectively $07(\square)$ and 14 days ( $\square$ ).

characteristic spectra of phototreated samples in the wavelength range of $200-600 \mathrm{~nm}$, so that all the chemicals and/or complexes in the solutions can be signalled at their maximum absorption wavelength. Once we identified the specific absorption wavelengths through the spectra, we chose these particular wavelengths for the analyses on the multiwavelengths Biomate 3 spectrophotometer during the field's application at the $2 \mathrm{iE}$ at Ouagadougou, Burkina Faso.
The biological Zahn Wellens tests were carried out on the phototreated samples after $60 \%$ degradation of the TOC, following the OCDE standard method [5].

The Chemical Oxygen Demand (COD) analyses were carried out via a Hach-2000 spectrophotometer using the dichromate solution as the oxidant in a strong acid medium. $2 \mathrm{~mL}$ of the samples were put into the low range kits $(0-$ $\left.150 \mathrm{mg} \cdot \mathrm{L}^{-1}\right)$ and digested at $150^{\circ} \mathrm{C}$ for two hours. Once the digested samples were cooled, their optical density was determined at $\lambda=430 \mathrm{~nm}$, in comparison to a blank, prepared with $2 \mathrm{~mL}$ of distilled water. The Biological Oxygen Demand for five days $\left(\mathrm{BOD}_{5}\right)$ was measured by means of an $\mathrm{Hg}$-free WTW 2000 Oxytop unit thermostated at $20^{\circ} \mathrm{C}$ according to the standard method.

\section{Results}

\subsection{A Systematic Study of the Photocatalytic Removal of the Chemical Pollution of the Industrial Wastewater in Switzerland}

3.1.1. Diagnosis: Physicochemical and Biological Characterization of Different Types of Effluents Resulting from the Processing of $L Q V$. Table 2 presents the characteristics of three effluents $\left(\mathrm{WW}_{i}\right)$ from the production of the LQV (its molecular 


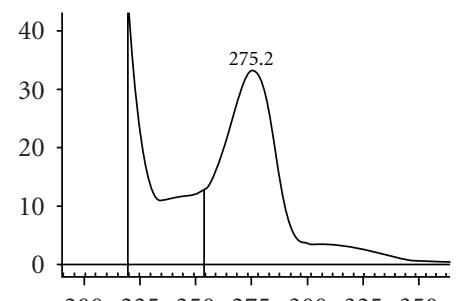

200225250275300325350 Wavelength $(\mathrm{nm})$

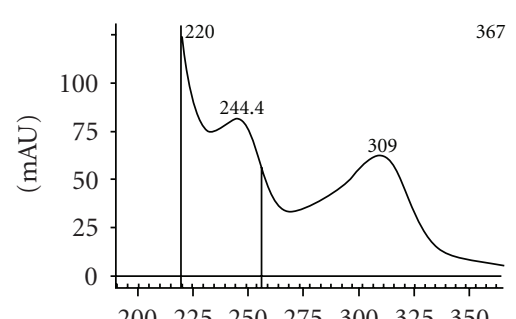

$200 \quad 225250275300325350$

Wavelength (nm)

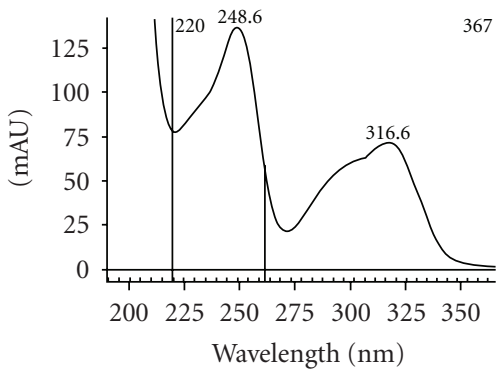

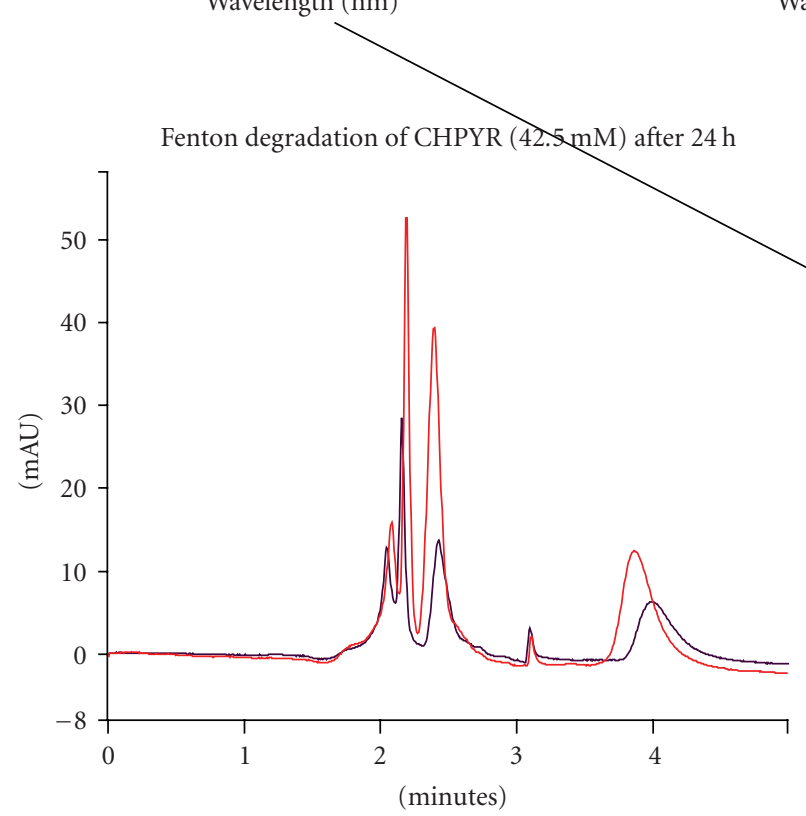
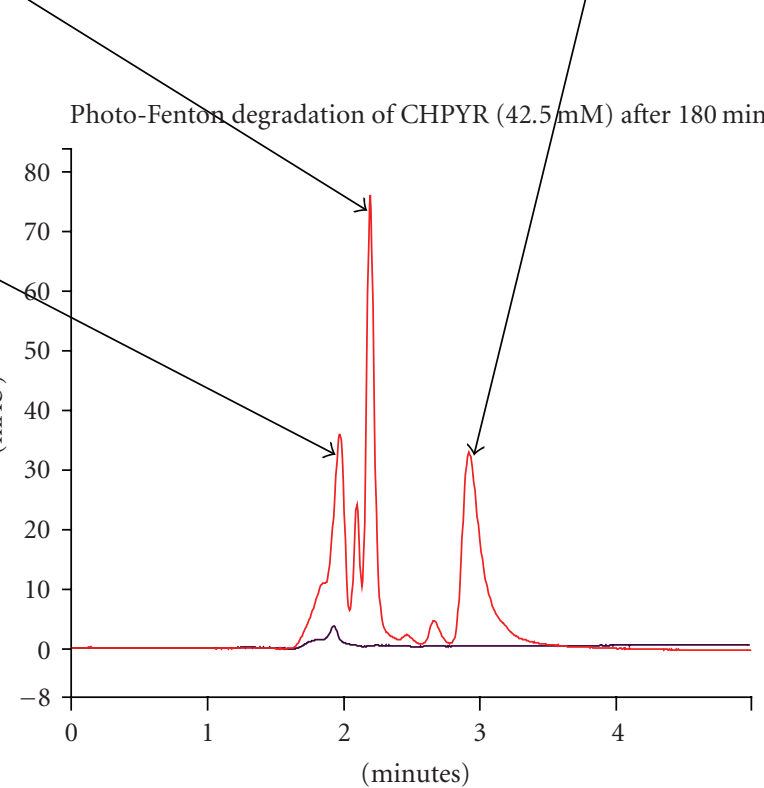

Figure 4: HPLC chromatograms of the CHPYR effluent before and after the Fenton (a) and the photoFenton (b) processes.

formula is confidential), and Figure 3 shows the results of the Zahn wellens tests carried out on the three effluents.

From these results, one can conclude the following.

(i) The wastewater mainly containing CTFEP is easily biodegradable and that with LQV is biodegradable after a certain periodfor bacteria adaptation.

(ii) The wastewater mainly containing CHPYR is biorecalcitrant. No change in the degradation rate was observed at the 7th, 14th, and up to the 28th day. The Fenton and photoFenton processes were applied to $\mathrm{WW}_{3}$, and the experimental conditions were optimized for the catalyst $\left(\mathrm{Fe}^{2+}\right)$ and the electronacceptor $\left(\mathrm{H}_{2} \mathrm{O}_{2}\right)$.

\subsubsection{Fenton and PhotoFenton Treatment of the CHPYR} Polluted Wastewater. Figure 4 shows the chromatograms of the CHPYR effluent carried out at the beginning and after 24 hours of Fenton treatment on 50\% diluted effluent on the one hand compared to the photoFenton treatment on the same effluent for $1 \mathrm{~h} 30$. The UV spectra of three significant peaks are observed on the raw effluent (nontreated). The two most important peaks of the chromatograms completely disappeared in case of the photoFenton treatment, and the one at $275.2 \mathrm{~nm}$ is $90 \%$ degraded; all the other peaks regressed relatively for $50 \%$ in case of the Fenton process after 24 hours.

3.1.3. Optimization of the $\mathrm{H}_{2} \mathrm{O}_{2}$ and $\mathrm{Fe}^{2+}$ Concentrations. Figure 5 shows that the optimal conditions for the photoFenton treatment of the CHPYR effluent are obtained in 2 hours with an initial concentration of the solution of TOC $=2200 \mathrm{mg} \cdot \mathrm{L}^{-1}, \mathrm{Fe}^{2+}=5.2 \mathrm{mM}, \mathrm{H}_{2} \mathrm{O}_{2}=768 \mathrm{mM}$. Under these conditions, $60 \%$ of the organic pollutants (main pollutants and their degradation intermediates) are mineralized when the CHPYR is completely exhausted in the solution within the two hours of photoFenton treatment.

3.1.4. Biodegradability of the PhotoTreated Effluent. Figure 6 shows the results of the OECD's Zahn Wellens test carried out on the phototreated CHPYR affluent under the optimal photoFenton degradation conditions $\left(\mathrm{Fe}^{2+}=5.2 \mathrm{mM}\right.$; $\mathrm{H}_{2} \mathrm{O}_{2}=768 \mathrm{mM} ; \mathrm{pH}=2.8$ ), with a decrease of $60 \%$ of total organic carbon. This shows that, relatively less than $15 \%$ to $18 \%$ of biological degradation is reached at the end of the first weeks followed by a fold down to $12 \%$ and stagnation until the 28th day. It is assumed that the photogenerated intermediates of degradation of the CHPYR are also biorecalcitrant or toxic. Hence a total mineralization following the Fenton or photoFenton process is necessary. 


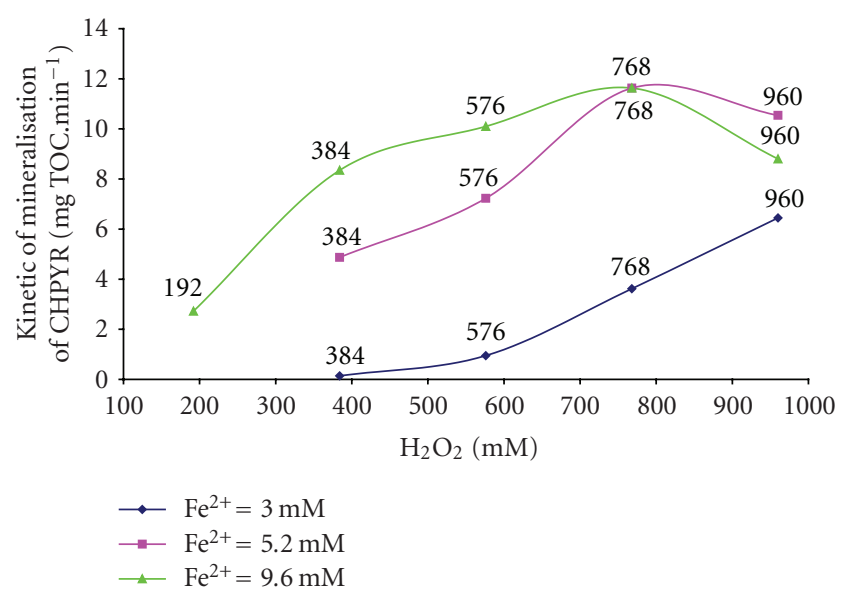

Figure 5: Kinetic of mineralisation of the CHPYR at various $\mathrm{H}_{2} \mathrm{O}_{2}$ concentration: (⿶) for $3 \mathrm{mM}$; $\left(_{\Delta}\right)$ for $5.2 \mathrm{mM}$ and $(\bullet)$ for $9.6 \mathrm{mM}$, as a function of the $\mathrm{H}_{2} \mathrm{O}_{2}$ concentration during the PhotoFenton process in a $50 \%$ diluted effluent $(42.5 \mathrm{mM})$.

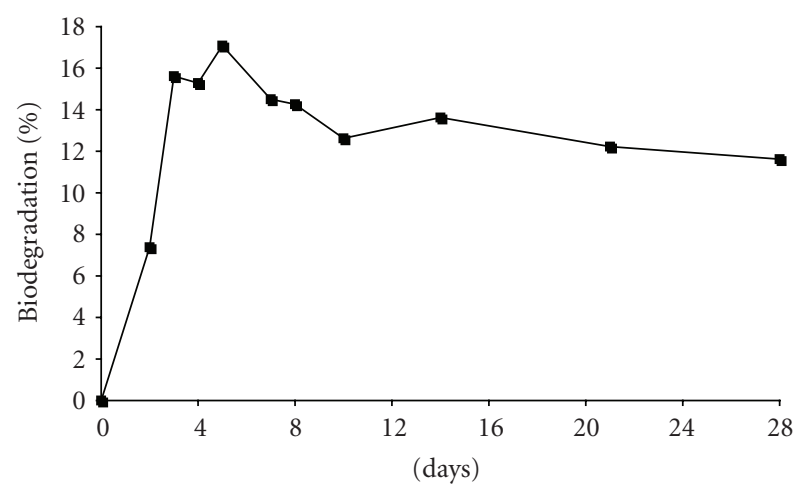

FIgURE 6: Evolution of the biodegradability following the Zahn Wellens process carried out on the CHPYR phototreated effluent.

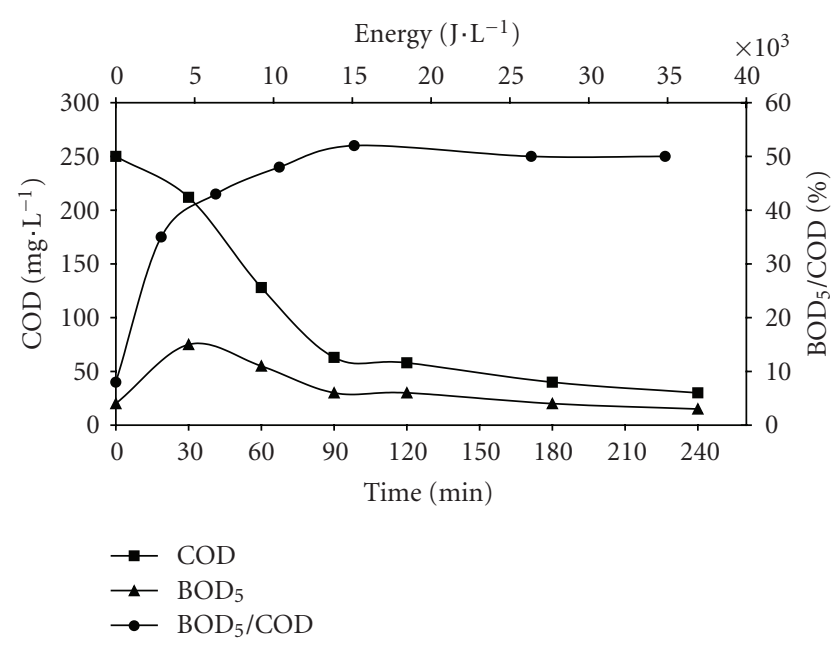

Figure 7: Evolution of biochemical parameter of the Endosulfan polluted water during the helio-photoFenton treatment, ( $\boldsymbol{\square})$ for the $\mathrm{COD},(\boldsymbol{\Lambda})$ for $\mathrm{BOD}_{5}$, and $(\bullet)$ for the $\mathrm{BOD}_{5} / \mathrm{COD}$ ratio.
3.2. Application of the Helio-PhotoFenton Process for the Degradation Wastewater Polluted with Endosulfan. The monitoring of the biodegradability of the solar-treated effluent was conducted on 30 minutes sampled effluents. The results in Figure 7 show that the $\mathrm{BOD}_{5}$ increases during the first 30 minutes of the treatment and decreases during the next hour; after that it remains constant. At the same time, the COD is continuously decreasing during one and half hour after which it remains constant. As a consequence of the evolution of these two parameters, the intrinsic biodegradability defined as the ratio $\mathrm{BOD}_{5} / \mathrm{COD}$ is continuously increasing up to $50 \%$ where it became constant when the energetic treatment factor of the process is $15 \times 10^{3} \mathrm{~J} \cdot \mathrm{L}^{-1}$.

\section{Discussions}

4.1. Study of the Management of the Chemical Industry Effluents. Figure 4 confirmed the presence of biorecalcitrant pollutant (CHPYR) with maximum UV absorption at $309 \mathrm{~nm}$. The studies carried out on the three types of effluents also showed that the effluents mainly containing LQV and of the CTFEP were biodegradable and only that of CHPYR was biorecalcitrant. However, the CHPYR effluent can be degraded through the Fenton and photoFenton processes, within the optimal conditions: $\left[\mathrm{Fe}^{2+}\right]=5.2 \mathrm{mM}$; $\left[\mathrm{H}_{2} \mathrm{O}_{2}\right]=768 \mathrm{mM}$ for effluent concentrated at $2.2 \mathrm{~g} \cdot \mathrm{L}^{-1}$ of CHPYR. However, the Fenton process was not timely efficient.

The Zahn Wellens tests carried out on the phototreated effluent up to $60 \%$ TOC reduction did not show any significant biodegradability meaning that the remaining carbonic components in the treated effluent still were biorecalcitrant. It would be preferable to phototreat the effluent totally (i.e., up to more than $90 \%$ mineralization).

For a better management of the effluents resulting from that manufacture, the following diagram in Figure 8 would be recommendable.

4.2. The Scaling up Approach from Laboratory Studies to the Field Application. Studies in the laboratory and within very high-tech experimental device potential, made it possible to highlight the applicability of the Fenton and photoFenton processes for the detoxification of non biodegradable pollution in water. However, since the aim of this research is to undertake this process for solving real problems, its scaling up applicability (on more significant volumes) still to be evaluated, particularly when operating using the sunlight and not the lamps which of course, are cost expensive. The example of the artificial contamination of water by Endosulfan in Burkina Faso approaches more the reality since cases of contamination of water of the ground water by the pesticides had been reported in Burkina [6].

It's possible that, by submitting the commercial pesticide which composed of the active component: the endosulfan (water solubility $\left(0.325 \mathrm{mg} \cdot \mathrm{L}^{-1}\right)$ and other additives such as emulsifiers and adhering agents (which stabilizes the product on the plant once it is pulverized) to the Fenton and photoFenton processes, some of these additives would 


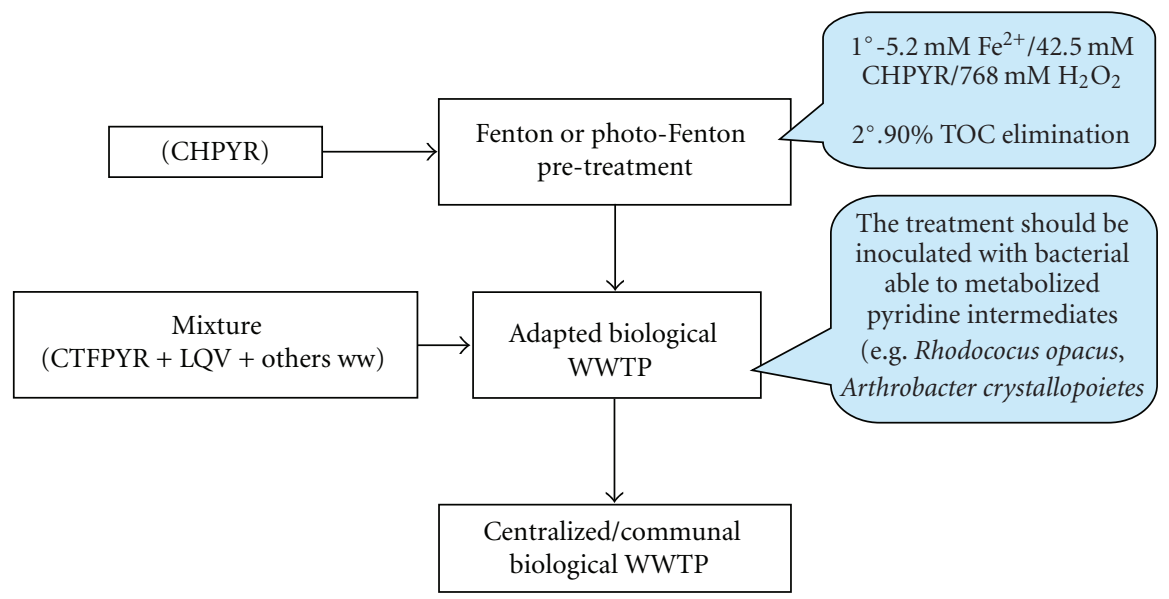

Figure 8: A proposed scheme of a diagram for the management of the studied effluents.

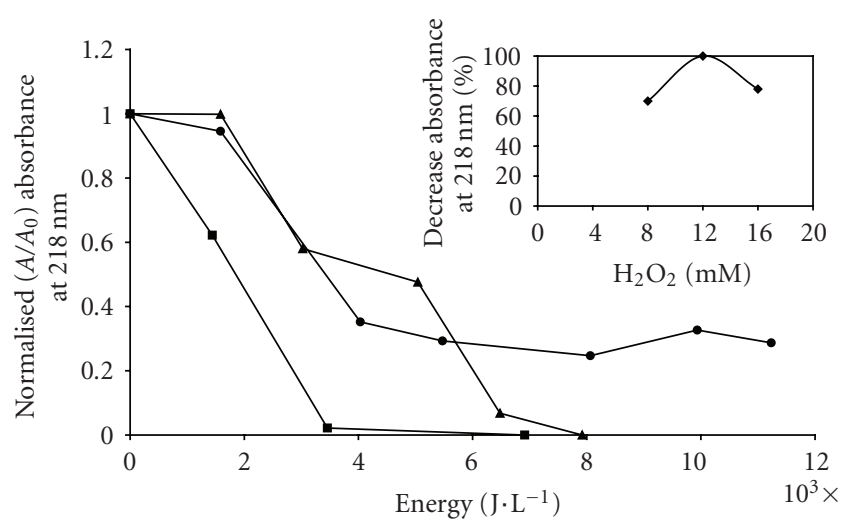

Figure 9: Relative absorbance of the phototreated Endosulfan contaminated water as a function of the specific energy. The $\mathrm{H}_{2} \mathrm{O}_{2}$ is varied from: $(\bullet) 8 \mathrm{mM},(\boldsymbol{\square}) 12 \mathrm{mM}$ to $(\Delta) 16 \mathrm{mM}$. The insert is percentage of relative degradation of the Endosulfan (monitored at $218 \mathrm{~nm}$ ) when $6 \times 10^{3} \mathrm{~J} \cdot \mathrm{L}^{-1}$ energy is accumulated in the photoreactor for the three $\mathrm{H}_{2} \mathrm{O}_{2}$ values tested.

be destroyed by photolysis and/or oxidation with oxygen from air [7]. The decrease of $40 \%$ of the absorbance at $218 \mathrm{~nm}$ as observed in Figure 9, does not inevitably mean that the Endosulfan is degraded, since it was shown that the molecule of Endosulfan is stable when exposed to solar radiation and the tests of stabilization for the commercial formulation of pesticides, taking into account the sunlight exposition aspects [8]. The effect of photolysis and aeration on the Endosulfan solution could be put into account of the degradation of the additives (emulsifiers and adherents).

Since the photocatalytic treatment is not considered as a cost effective process when compared to biological treatment [9-12], when taken into account the cost of hydrogen peroxide on the one hand, the technical choice of a treatment, total photochemical mineralization or coupling photochemical-biological processes, on the other hand, it is necessary to make a compromise over the optimal concentration of $\mathrm{H}_{2} \mathrm{O}_{2}$ and the duration of the treatment, by considering the biodegradability of the phototreated effluent. In the case of this study, the choice was made on the lowest concentration of the peroxide $(8 \mathrm{mM})$ with $0.18 \mathrm{Fe}^{2+} \mathrm{mM}$ for an initial concentration of $0.36 \mathrm{mM}$ of Endosulfan, conditions within which, is that $50 \%$ of the biodegradability of the phototreated effluent is reached after $1 \mathrm{~h} 30$.

Assuming the relatively high value of the $\mathrm{BOD}_{5} / \mathrm{COD}$ ratio noticed in Figure 7 , one can conclude that the phototreated pesticide effluent containing Endosulfan can become biodegradable in the natural environment. However, it would be necessary to send such effluents into a biological wastewater treatment plant before they could be reused for any purpose or be rejected in the natural media (river, dam, or lake) following the scheme proposed in Figure 8.Otherwise, more studies need to be carried out, that is, by coupling photochemical and a biological process to oversee the complete degradation of endosulfan polluted water.

\section{Conclusion}

The difficulty and the complexity of treating real biorecalcitrant wastewaters were observed within the two studied cases. The increase of the biodegradability was observed after the photoFenton treatment of the effluent contaminated with Endosulfan but not with the CHPYR effluent. Thus, a total mineralization process is recommendable in the second case and rather an improvement of the biodegradability of the Endosulfan effluent.

The study on the pesticide effluent enables one to notice that the photolysis could lower by $30 \%$ the COD of the effluent (Figure 9) by contrast to the absence of COD decrease for a simple aeration.

In the two case studies, the helio-photoFenton process is effective proportionally to the amount of hydrogen peroxide added; but for economic reasons, a compromise should be made between the highest kinetics of the treatment process of the Endosulfan effluent and the overall objective (or strategy) 
of the treatment, namely, the coupling of photochemical and biological processes which is a cost minimization option in the treatment strategies of biorecalcitrant wastewaters.

Is the high $\mathrm{DBO}_{5} / \mathrm{DCO}$ ratio in the case of the photodegradation of Endosulfan effluent necessarily a good indicator to confirm the biotreatability of the phototreated effluent? Such a request could be looked out through very concise chemical analyses of the components of the effluents.

Eventually, this study shows a soft approach of transferring a laboratory high-tech context study to a field applied context within a North-South cooperation.

\section{Acknowledgments}

This work was supported by the Swiss Federal Department for the Cooperation throughout the fifth EPFL2iE-DDC convention (2002-2006), the NCCR-NS research programme- IP 4-JACS-WA, the EPFL student association "Ingénieurs du Monde", and the EPFL-Colombia Environment Programme. The authors are very gratefully to MM. Cesar Lador, former student at the EPFL, and Amadou Zakari Yeou from the International Institute of Water and Environmental Engineering (2iE) who jointly did an internship works training in this project during the Easter 2005. Beside them, MM Bernard Zongo and Jules Ouédraogo are also thanked for their help during the field work at the $2 \mathrm{iE}$ experimental water treatment platform in Ouagadougou, Burkina Faso.

\section{References}

[1] Population.Information.Program, "Solutions for a watershort world," 1-31, 1998.

[2] K. Toepfer, "Statement on the occasion of the Stockholm Convention on Persistent Organic Pollutants Coming into Force," UNEP, 2004.

[3] J. Blanco and S. R. Malato, "Solar detoxification," Alméria, UNESCO/PSA, 2001.

[4] G. S. Kwon, H. Y. Sohn, K. S. Shin, E. Kim, and B. I. Seo, "Biodegradation of the organochlorine insecticide, endosulfan, and the toxic metabolite, endosulfan sulfate, by Klebsiella oxytoca KE-8," Applied Microbiology and Biotechnology, vol. 67, pp. 845-850, 2005.

[5] OECD, "Guidelines for testing of chemicals," test 302 B, 1996.

[6] H. K. Tapsoba and Y. L. Bonzi-Coulibaly, "Production cotonnière et pollution des eaux par les pesticides au Burkina Faso," Journal de la Société Ouest-Africaine de Chimie, no. 21, pp. 87-93, 2006.

[7] N. Sethunathan, M. Megharaj, Z. Chen, N. Singh, R. S. Kookana, and R. Naidu, "Persistence of endosulfan and endosulfan sulfate in soil as affected by moisture regime and organic matter addition," Bulletin of Environmental Contamination and Toxicology, vol. 68, no. 5, pp. 725-731, 2002.

[8] K. P. Bentson, "Fate of xenobiotics in foliar pesticide deposits; reviews of environmental contamination and toxicology," CODEN RCTOE4, vol. 114, pp. 125-161, 1990.

[9] D. F. Ollis, "Process economics for water purification: a comparative assessment," in Photocatalysis and Environment, pp. 663-677, Kluwer Academic Publishers, Boston, Mass, USA, 1988.

[10] C. Pulgarin, M. Invernizzi, S. Parra, V. Sarria, R. Polania, and P. Péringer, "Strategy for the coupling of photochemical and biological flow reactors useful in mineralization of biorecalcitrant industrial pollutants," Catalysis Today, vol. 54, no. 2-3, pp. 341-352, 1999.

[11] J. Blanco and S. R. Malato, "Solar detoxification," Alméria, UNESCO/PSA, 2003.

[12] V. Sarria, S. Kenfack, O. Guillod, and C. Pulgarin, "An innovative coupled solar-biological system at field pilot scale for the treatment of biorecalcitrant pollutants," Journal of Photochemistry and Photobiology A, vol. 159, no. 1, pp. 89-99, 2003. 


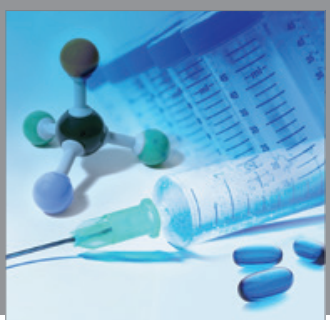

International Journal of

Medicinal Chemistry

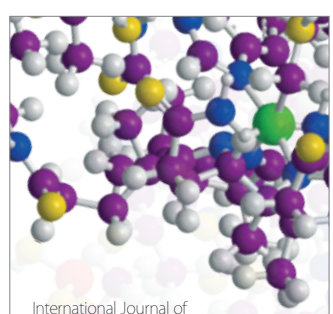

Carbohydrate Chemistry

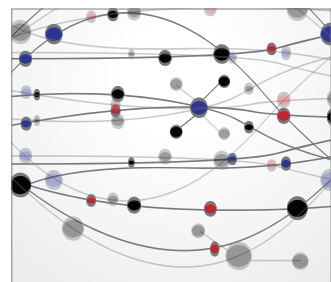

The Scientific World Journal
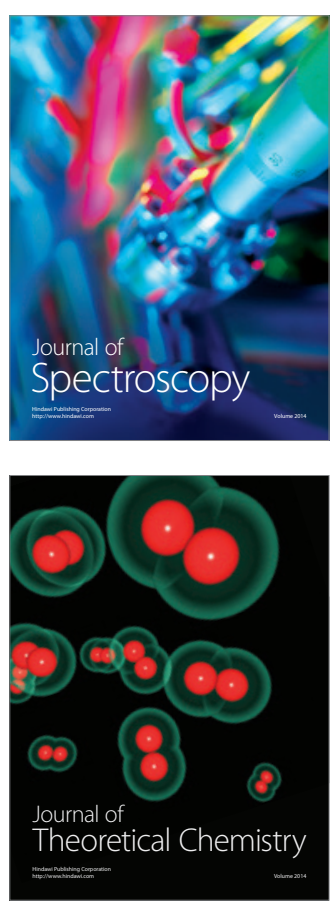
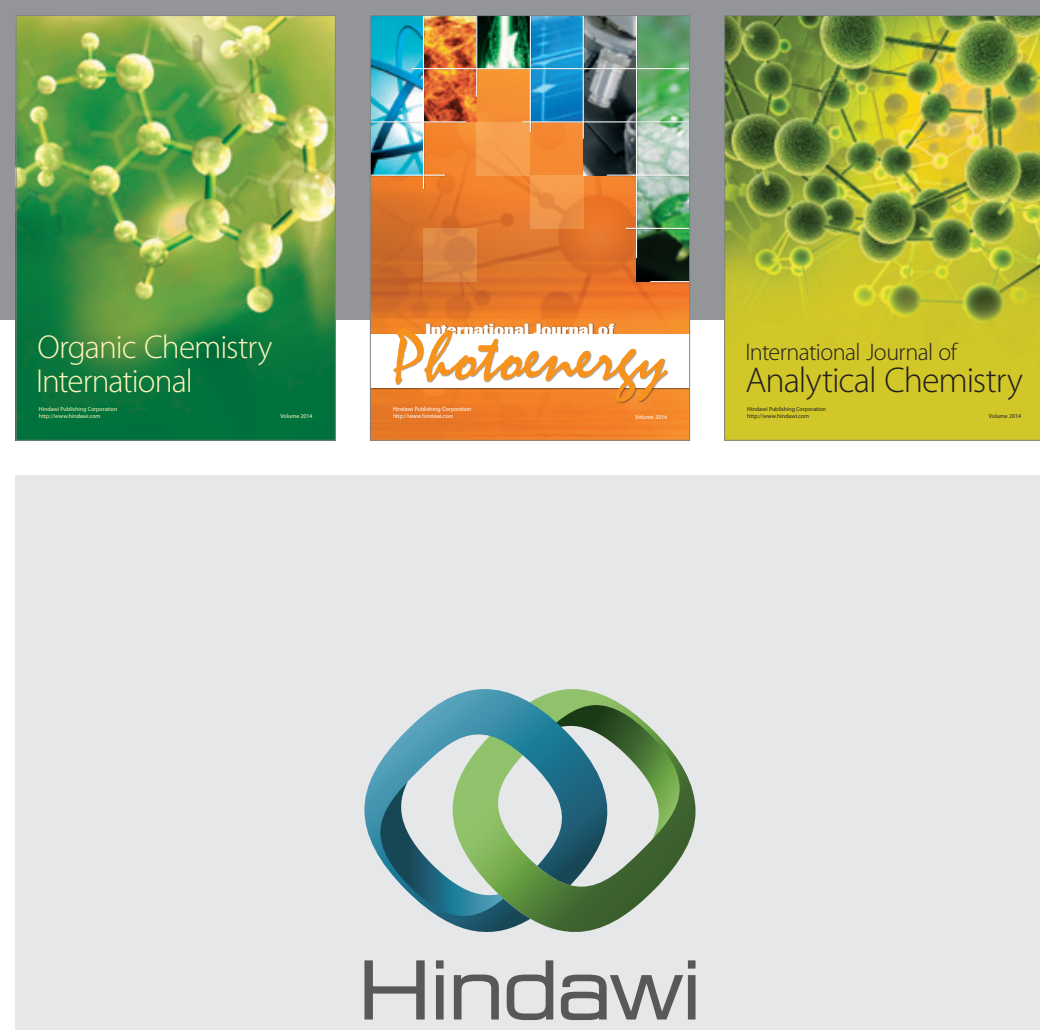

Submit your manuscripts at

http://www.hindawi.com
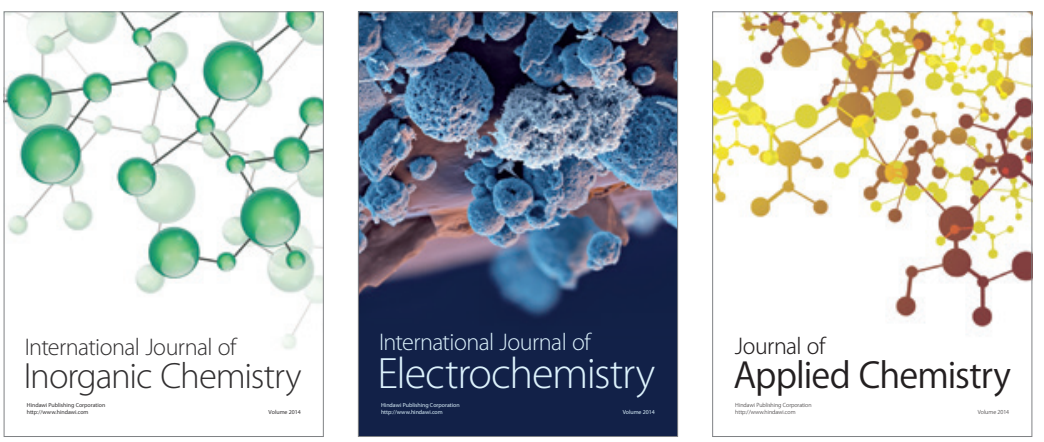

Journal of

Applied Chemistry
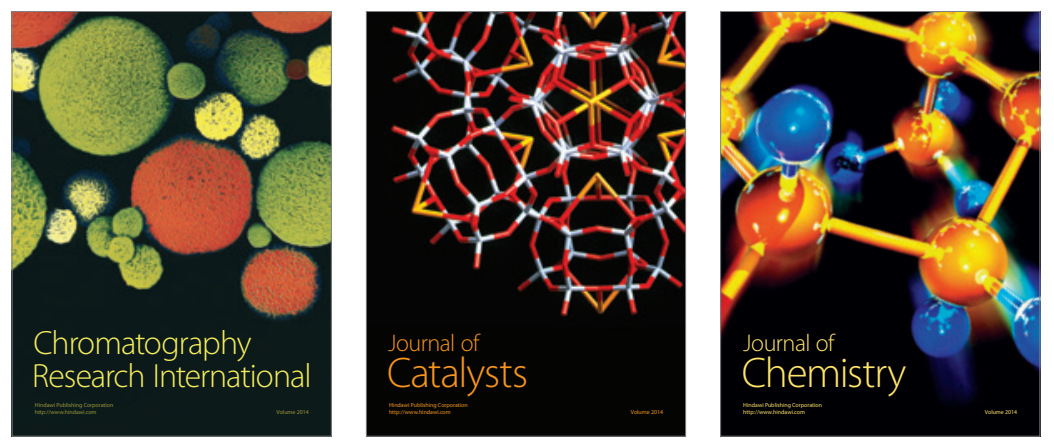
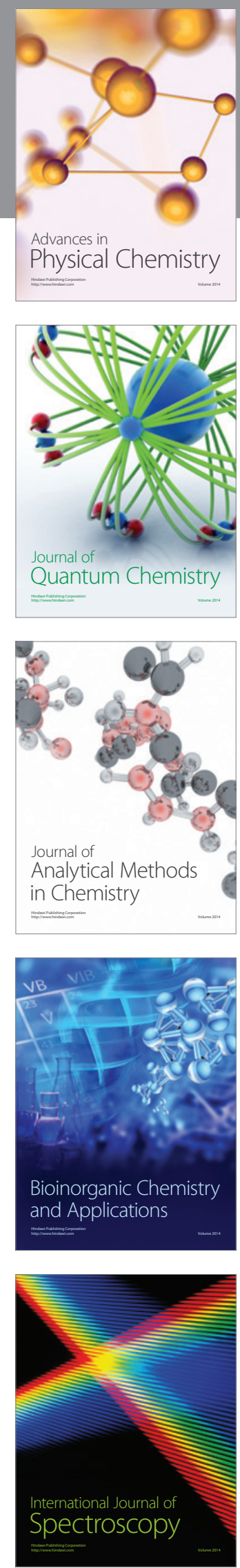